\title{
mant \\ Combining Project Based Learning and Cooperative Learning Strategies in a Geotechnical Engineering Course
}

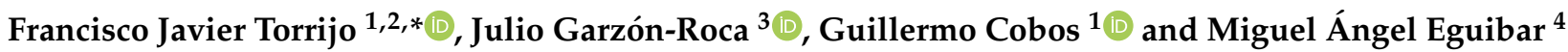 \\ 1 Department of Geological and Geotechnical Engineering, Universitat Politècnica de València, \\ 46022 Valencia, Spain; gcobosc@trr.upv.es \\ 2 Research Centre PEGASO, Universitat Politècnica de València, 46022 Valencia, Spain \\ 3 Department of Geodynamics (GEODESPAL), Faculty of Geology, Complutense University of Madrid, \\ 28040 Madrid, Spain; julgarzo@ucm.es \\ 4 Institute for Water and Environmental Engineering (IIAMA), Department of Hydraulic Engineering \\ and Environment, Universitat Politècnica de València, 46022 Valencia, Spain; meguibar@hma.upv.es \\ * Correspondence: fratorec@trr.upv.es
}

check for updates

Citation: Torrijo, F.J.; Garzón-Roca, J.; Cobos, G.; Eguibar, M.Á. Combining Project Based Learning and Cooperative Learning Strategies in a Geotechnical Engineering Course. Educ. Sci. 2021, 11, 467. https:// doi.org/10.3390/educsci11090467

Academic Editor: João Piedade

Received: 19 July 2021

Accepted: 19 August 2021

Published: 25 August 2021

Publisher's Note: MDPI stays neutral with regard to jurisdictional claims in published maps and institutional affiliations.

Copyright: (c) 2021 by the authors. Licensee MDPI, Basel, Switzerland. This article is an open access article distributed under the terms and conditions of the Creative Commons Attribution (CC BY) license (https:/ / creativecommons.org/licenses/by/ $4.0 /)$.

\begin{abstract}
This paper presents the implementation of a learning methodology following a studentcentred approach. The methodology is based on the use of project based and cooperative learning and mainly consists of commissioning students to prepare a presentation on a topic of their subject. Students work in groups, and later must deliver a real lecture to their colleagues. The proposed methodology was applied across 7 years and its implementation was monitored via day-to-day observations, annual surveys, the gathering of direct feedback as well as by analysing the students' academic performance. Results show the ability of the proposed learning methodology to enhance motivation and engagement of students, facilitate the improvement of four soft skills (team-working, practical thinking, effective communication and critical thinking), eliminate absenteeism and facilitate long-term retention of the knowledge and skills acquired in a subject.
\end{abstract}

Keywords: active learning; higher education; project based learning; cooperative learning

\section{Introduction}

Higher education is characterized by the need of preparing students for their future profession [1]. This translates into ensuring students develop knowledge and skills (the former meaning the student's capacity to understand the subject's contents $[2,3]$ and the latter denoting the different abilities acquired by the student [4]) in several areas, including both the specific topics of their field under study and those aspects requested by the actual job market, such as clear thinking and team-working [5]. Moreover, students must be able to apply what they have learned [6] as well as develop the ability to learn autonomously [7].

The classical teaching of higher education, however, is based on a teacher-centric approach, with the transmission of great theoretical and technical information by the teacher, who undertakes most of the work [8], whilst students are passive receivers of such information watching and listening [9]. This scenario often leads to low motivation and high absenteeism in students, and makes it difficult the acquisition of professional and soft skills [10] as well as developing a deep-level learning [11] of any knowledge.

The use of active learning methodologies, following a student-centred approach, are promising tools in higher education to tackle the previous issues [1,12]. Among these methodologies, Project Based Learning (PBL) is becoming a common pedagogical methodology in higher education, having been used in different STEM areas, including Civil Engineering [13-15]. PBL essentially consists of assigning the students one or several tasks that lead to creating meaningful products or results [16,17]. In this learning approach, the teacher acts mainly as a facilitator $[1,18]$. PBL was shown to increase learning effectiveness, helping in developing both technical and non-technical knowledge as well as 
skills $[6,13,18-24]$. In particular, PBL contributes to developing some specific soft skills, such as self-directed learning, critical thinking, theory-practice relationships and problem solving [25]. It also increases the students' motivation whilst offering them the possibility of including real-world experiences in their day-to-day learning [26].

Cooperative learning is another well-known active learning methodology that works well when paired with PBL $[27,28]$. Cooperative learning consists of involving the students in team-working activities to reach individual and group learning goals, as well as facilitating sharing of knowledge and learning from others through discussions and social interaction [29-31]. The use of cooperative learning leads to an improvement of learning outcomes besides fostering teamwork capabilities. Literature shows several examples of the benefits for students of applying such a strategy in higher education and engineering courses [31-37].

This paper presents how PBL and cooperative learning can be combined to create a learning methodology capable of increasing the students' motivation, awaking their interest in the topics studied [38,39], whilst facilitating the acquisition and improvement of four soft skills: team-working, practical thinking, effective communication and critical thinking. The learning methodology proposed followed the work developed in prior teaching experiences by the authors [40-43], which involved the development of one of the topics taken from the subject curriculum by students themselves, who then had to prepare and give a real lecture to their classmates.

This methodology was applied to a subject related to Geotechnical Engineering belonging to the last year (4th year) of the Civil Engineering Degree taught at the Civil Engineering School at the Technical University of Valencia. The experience lasted 7 academic years (from the year 2013/2014 up to the year 2019/2020) and involved more than 650 students. It is interesting to note that the methodology was developed as an opportunity to adapt the subject to the European Higher Education Area (EHEA) education approach due to the Bologna Process, which requires a series of soft skills to be included in the students curricula. A student-centred approach was considered the optimal way to develop and assess such skills, whilst increasing at the same time the students' motivation.

The success of the methodology was controlled by several instruments. Day-to-day observations were conducted and, together with an annual survey, they monitored the implementation of the methodology as well as students' satisfaction. Besides, the direct opinion of the students was gathered each course after finishing the subject, complementing the information obtained and receiving feedback. Finally, the academic performance was recorded and analysed, showing that, along with the soft skill acquisitions, students' grades are enhancec and absenteeism nearly disappears.

\section{Materials and Methods}

\subsection{Context}

The learning methodology was implemented in the subject "Geotechnical Engineering, Techniques and Methods" taught at the Civil Engineering School at the Technical University of Valencia. The subject belongs to the 4th year of the Degree in Civil Engineering, has a total of $60 \mathrm{~h}$ and is mandatory for all students.

This subject was introduced in the Civil Engineering Degree as a result of the implementation of the Bologna Process. The first academic year in which it was taught was 2012/2013. That year, a traditional approach based on a completely teacher-centred methodology was used. Implementation of the described learning methodology started in the second academic year, i.e., the year 2013/2014, and lasted 7 years, up to the academic year 2019/2020. Thus, the first year may be used as a "reference year".

\subsection{Participants}

Students attending the subject were between 21 and 25 years old and about $1 / 3$ were female. Figure 1 shows the evolution of the number of students enrolled in the subject along the different academic years as well as those who abandon the subject and/or (from 
the year 2013/2014) decided not to follow the proposed learning methodology described in this paper. It should be mentioned that following the methodology was optional according to the Civil Engineering School policies; however, nearly $90 \%$ of the students follow the proposed learning methodology each year.

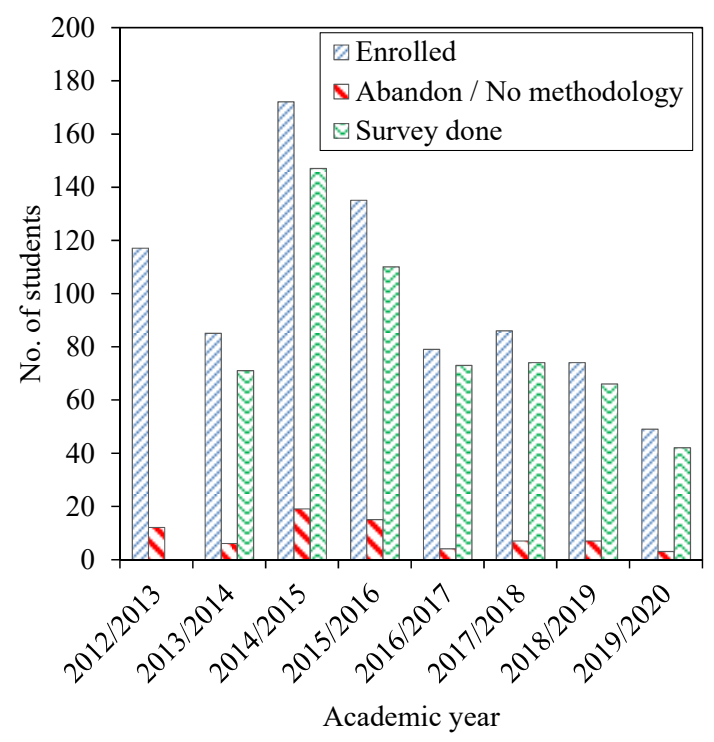

Figure 1. Evolution of the number of students; the proposed learning methodology was implemented in the academic year 2013/2014: the academic year 2012/2013 serves as a reference year.

The total number of students enrolled in the subject greatly varied from a maximum of 172 students during the academic year 2014/2015 to a minimum of 49 students in the academic year 2019/2020. These fluctuations responded to the number of students that decide to study Civil Engineering each year and finally arrive at the 4th year where the subject was taught. This difference in the number of students may introduce some disturbance when assessing the performance of the methodology since active learning strategies normally work better with a reduced number of students. The implementation of the proposed learning methodology was conducted in the academic year 2013/2014. That moment was considered to be appropriate due to the low number of students when compared to the ones expected in the following years.

\subsection{Learning Methodology}

The learning methodology consists of the preparation of a real $2 \mathrm{~h}$ lecture on a relevant topic chosen by students themselves. Students work in groups of 3-5 people (depending on the total number of students). The activity is intended to be done outside the class time by the students throughout the semester. Once the lecture is ready, the group also must teach it to their classmates during a common class session. To prepare the lecture and guide the students, each group has the help of one of the teachers of the subject, who tutors the group and controls the pace of the work through a series of periodic meetings. Thus, each group is responsible for one of the lectures on the subject, and insodoing take on the teacher's classical role.

The methodology combines PBL and cooperative learning. Here, PBL is applied in terms of commissioning the students a project. That project is the preparation of a real lecture, which may be considered an authentic and significant task when the topic under study, and later to be taught, is related to a specific field or area of the student's future profession. Students may consider it suitable to introduce in their lecture common expositive parts (following the classical Master's lesson) as well as activities such as simulations, discussions, video visualizations, exercises, assessments and development of real cases. Since all the work conducted by the students is done in a group, cooperative learning effects also arise in the methodology. Cooperative learning even extends to the 
lecture itself time: whilst in their teaching role, the students in charge of the class have the opportunity to comment and discuss the topic with their colleagues, which reinforces the learning of both the students-teachers and the rest of the students.

The methodology also helps in developing several soft skills in students, including team-working (collaboration, cooperation and organization between the group members), practical thinking (the group has to make decisions about what to teach and how to present it, keeping in mind the knowledge of their classmates), effective communication (the group has to clearly transmit their message, i.e., the topic under study) and critical thinking (each member of the group has to understand the issues of the topic taught, and "the why" of the content). Moreover, preparing a lecture means analysing and evaluating the topic under study, and sometimes also requires creating new information. Those three cognitive levels (analysing, evaluating and creating) correspond to the three highest learning skills (higher-order skills) according to Bloom's taxonomy [44]. Due to all these aspects, the methodology is especially suitable for its use in subjects belonging to the last years of higher education courses, such as $3^{\text {rd }}$ and $4^{\text {th }}$ degree years, or in a Master's degree.

The tutor in charge of each group has the role of a facilitator. In the meetings with the group, the tutor can instruct the students about the optimal ways for preparing and later delivering the lecture as well as providing the group with the needed basic bibliography and resources to undertake their task. The tutor can also provide feedback once the group has proposed their idea about the lecture preparation, how to teach it, which documentation deliver to "their students" (i.e., their classmates), how to not create passiveness in the rest of the class and so on. Thus, even though the methodology aims to put some lectures of a subject entirely under the students' responsibility, the tutor can always be there to supervise the work, control its quality and guide the group to achieve the best performance of any member.

For evaluating the students' performance in the subject, a co-evaluation strategy is proposed, based on two items of a similar weight and based on a rubric: (i) a peer evaluation conducted by those classmates who were present in the lecture given by the group; and (ii) an evaluation conducted by the tutor who supervised the group. Item (ii) may be replaced by an exam if considered appropriate to control the students' learning. That exam may be an objective test dealing with the main aspects covered by the students' lectures or an open answer written test with exercises. In any case, the tutor of each group should be particularly cautious with the material delivered by the students group to their classmates, so they can properly prepare for the exam.

\subsection{Implementation}

The subject where the learning methodology was implemented was divided into two parts. Figure 2 shows the subject syllabus distribution. The learning methodology described in this paper was applied to the second part, whilst topics belonging to the first part were taught based on a more classical teacher-centred approach.

The Master's lesson was used during that first part, combining it with flip teaching [45], an instructional active strategy largely applied in higher education and engineering courses $[4,31,44-53]$. Flip teaching is aimed at making students understand contents before attending classes, so that class time can be used to undertake activities designed for developing higher-order thinking skills. Thus, this first part of the subject was apparently similar to the classical higher education lectures, with topics of an academic nature in which the role of the teacher in structuring the concepts (as well as giving some explanations) is relevant. However, the use of flip teaching enabled the teacher not to have a complete leadership and prepared the field for the active learning strategy to be used in the second part, which contained topics of an expositive nature, application of theoretical concepts, professional case studies and issues related to the practitioner work.

There were some reasons why the whole subject was not developed following the proposed learning methodology. First, purely implementation of any true active methodology in class is not common in the Civil Engineering School at the Technical University of 
Valencia, where more than $75 \%$ of the subjects are completely taught following the classical teaching of higher education. Thus, using the Master's lesson during the first weeks of the course leads to reducing the potential "distress level" that some students can experience when active learning strategies are introduced in class, which also gives each group of students more time to prepare for their future lectures.

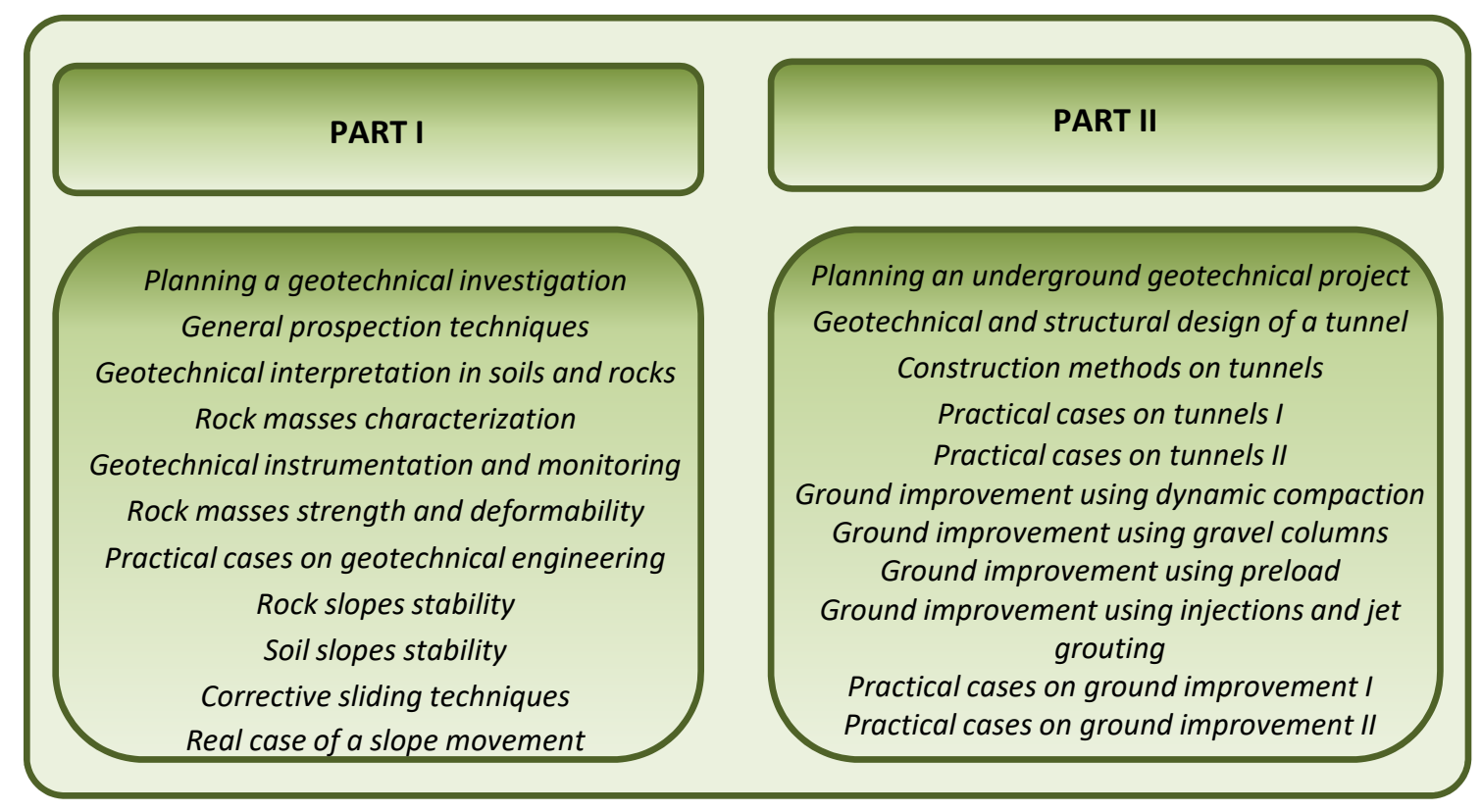

Figure 2. Subject syllabus distribution.

In addition, the Civil Engineering School policies did not allow evaluation of a subject based on a unique activity. Thus, by dividing the subject into two parts, the students were evaluated based on two assessment instruments, one (first part, teacher-centred) by means of an open answer written test and a second co-evaluation based on the lectures given by the students following the learning methodology proposed here. Particularly, for the evaluation of the second part, the co-evaluation process mentioned in the previous section was applied. From the year 2013/2014 to the year 2016/2017, the tutor of each group provided the "teacher's part" of the co-evaluation, with the assessment being based on the group performance throughout the semester; from that year (last three years), that assessment was replaced by an open-written test.

\subsection{Instruments and Monitoring}

\subsubsection{Day-to-Day Observations}

A day-to-day observation was conducted and recorded by the tutor of each group, as well as by the teachers at every class session during both the first and the second part of the subject. Notes were continuously taken about the development of the subject and the evolution of students, being later discussed in a meeting involving all the teachers of the subject held with a periodicity of a month. During the first part of the subject, these observations were aimed at assessing the students' ease of acquiring knowledge, their base motivation towards the subject, and the natural flow of the sessions. Particularly, at meetings, the evolution of students in terms of their active approach was assessed, analysing how flip teaching activities implemented and especially the fact of having to prepare in the future a real lecture helped towards it.

Regarding the second part of the subject, discussion in meetings dealt with the path of the work developed by each group and how the students were adapting themselves to their new role as teachers. Moreover, the performance of each group was evaluated, from the notes taken by the corresponding tutor and their sharing with the rest of teachers, using the rubric showed in Table 1, deliberately developed for this subject. This rubric was based 
on the four soft skills that the learning methodology proposed pretended to develop, along with managing information (added to assess the convenience and completeness of the resources used by each group for preparing the lecture). The conclusions at each meeting were written down by the corresponding tutor and later given as feedback to students in their next meeting with them. The rubric set was also used later by the tutors for carrying out the co-evaluation of their groups (students evaluated their colleagues using this rubric as well, but only making reference to practical thinking, critical thinking and effective communication skills).

Table 1. Rubric developed for assessing the acquisition of soft skills.

\begin{tabular}{|c|c|c|c|c|}
\hline Skill & Poor & Fair & Good & Excellent \\
\hline $\begin{array}{l}\text { Team-working } \\
\text { (cooperation and } \\
\text { organization) }\end{array}$ & $\begin{array}{l}\text { Group members appear to } \\
\text { do each one their own } \\
\text { thing; member's roles are } \\
\text { not defined at all }\end{array}$ & $\begin{array}{c}\text { Some cooperation is seen, } \\
\text { but one or two members } \\
\text { are who carry most of the } \\
\text { work; member's roles are } \\
\text { not well defined }\end{array}$ & $\begin{array}{c}\text { Group members cooperate } \\
\text { with each other but } \\
\text { sometimes a member } \\
\text { works on their own; } \\
\text { member's roles are } \\
\text { defined }\end{array}$ & $\begin{array}{l}\text { Group members fully } \\
\text { cooperate, member's roles } \\
\text { are correctly defined and } \\
\text { work developed involves } \\
\text { all group members }\end{array}$ \\
\hline $\begin{array}{l}\text { Managing information } \\
\text { (resources used for } \\
\text { preparing the lecture) }\end{array}$ & $\begin{array}{l}\text { Material developed is } \\
\text { nearly inexistent; the } \\
\text { bibliography and } \\
\text { resources provided by the } \\
\text { tutor are not used }\end{array}$ & $\begin{array}{l}\text { Material developed almost } \\
\text { exclusively comprises the } \\
\text { basic bibliography and } \\
\text { resources provided }\end{array}$ & $\begin{array}{c}\text { Material developed } \\
\text { mainly comprises the } \\
\text { basic resources provided, } \\
\text { but some additional one is } \\
\text { added }\end{array}$ & $\begin{array}{l}\text { Material developed } \\
\text { involves the basic } \\
\text { resources provided and } \\
\text { new ones gathered by the } \\
\text { group }\end{array}$ \\
\hline $\begin{array}{c}\text { Practical thinking } \\
\text { (decision making about } \\
\text { teaching material) }\end{array}$ & $\begin{array}{l}\text { Key information for } \\
\text { preparing the lecture is not } \\
\text { properly identified and } \\
\text { aspects considered deviate } \\
\text { from the main topic }\end{array}$ & $\begin{array}{l}\text { Some of the key } \\
\text { information is identified, } \\
\text { but there are aspects } \\
\text { considered for the lecture } \\
\text { that deviate from the main } \\
\text { topic }\end{array}$ & $\begin{array}{l}\text { The key information is } \\
\text { identified, but the lecture } \\
\text { also covers several side } \\
\text { material that may } \\
\text { introduce some noise in } \\
\text { the main message }\end{array}$ & $\begin{array}{l}\text { The key information is } \\
\text { identified and lecture } \\
\text { preparation is focused on } \\
\text { that, leaving the rest of the } \\
\text { information as } \\
\text { supplementary material }\end{array}$ \\
\hline $\begin{array}{c}\text { Critical thinking } \\
\text { (understanding the issues } \\
\text { of the topic taught) }\end{array}$ & $\begin{array}{l}\text { Nearly none of the } \\
\text { members seem to } \\
\text { understand the main } \\
\text { concepts of the topic } \\
\text { taught, they do not control } \\
\text { it and are often confused }\end{array}$ & $\begin{array}{l}\text { Some of the members } \\
\text { seem to understand the } \\
\text { main concepts of the topic } \\
\text { taught, but other members } \\
\text { do not control the topic } \\
\text { and are sometimes } \\
\text { confused }\end{array}$ & $\begin{array}{l}\text { All the members seem to } \\
\text { fully understand the main } \\
\text { concepts of the topic } \\
\text { taught }\end{array}$ & $\begin{array}{l}\text { All the members seem to } \\
\text { fully understand the main } \\
\text { concepts of the topic } \\
\text { taught and even are able } \\
\text { to propose new ideas for } \\
\text { further development of it }\end{array}$ \\
\hline $\begin{array}{l}\text { Effective communication } \\
\text { (lecture presentation) }\end{array}$ & $\begin{array}{l}\text { Some difficulty in } \\
\text { expressing with clarity the } \\
\text { message is detected; } \\
\text { communication is poor } \\
\text { with little interaction with } \\
\text { the audience; the } \\
\text { presentation layout is } \\
\text { confusing }\end{array}$ & $\begin{array}{l}\text { Though the message is } \\
\text { given with some difficulty } \\
\text { and with little interaction } \\
\text { with the audience, the } \\
\text { presentation layout helps } \\
\text { understand the topic } \\
\text { concepts }\end{array}$ & $\begin{array}{l}\text { The message is expressed } \\
\text { with clarity and } \\
\text { interacting with the } \\
\text { audience; the presentation } \\
\text { layout is good and helps } \\
\text { understand the topic } \\
\text { concepts }\end{array}$ & $\begin{array}{l}\text { The message is expressed } \\
\text { with clarity, interacting } \\
\text { with the audience and } \\
\text { motivating them to be } \\
\text { active; the presentation } \\
\text { layout is good and helps } \\
\text { understand the topic } \\
\text { concepts }\end{array}$ \\
\hline
\end{tabular}

\subsubsection{Survey}

The implementation of the methodology was further monitored each course by a survey with 10 questions (see Table 2), delivered at class during the last two weeks of the subject. The aim of the survey was having a holistic view of the learning methodology and was not focused on the development of any particular soft skill. The survey was individual, anonymous and not compulsory (Figure 1 shows the number of students who filled the survey per course). Each question was scored from 1 to 5 , where the higher the score the higher the agreement with the question (i.e., 1 means "totally disagree", whilst 5 means "totally agree"). To avoid an automatic filling of the survey, not every question with a score of 5 resulted in a "totally positive" answer and vice versa (see for instance question 8).

The three first questions (1,2 and 3 ) assessed engagement and motivation. The second three questions $(4,5$ and 6$)$ measured the success of the methodology to facilitate active learning in students. The third three questions $(7,8$ and 9$)$ were related to autonomous learning and the workload imposed by the methodology; these questions also tried to measure the capability of the methodology for getting good learning results (acquisition of knowledge and skills) in an optimal way when compared with other more classical approaches. The last question (10) was an indicator of the global satisfaction of the stu- 
dents, by asking them if they would recommend future colleagues to get enrolled in the methodology.

Table 2. Survey questions.

\begin{tabular}{|c|c|c|}
\hline Question No. & Question Description & Topic \\
\hline 1 & \multirow{3}{*}{$\begin{array}{l}\text { The learning methodology allows following the subject easily } \\
\text { The learning methodology increases my involvement in the subject when compared with other } \\
\text { subjects } \\
\text { The learning methodology facilitates the teacher-student relationship }\end{array}$} & \multirow{3}{*}{$\begin{array}{l}\text { Motivation and } \\
\text { engagement }\end{array}$} \\
\hline 2 & & \\
\hline 3 & & \\
\hline 4 & \multirow{2}{*}{$\begin{array}{l}\text { The learning methodology makes me see the teacher as a guide rather than a pure examiner } \\
\text { Having to prepare for a real class drives me to make better use of the time during most of the } \\
\text { subject sessions }\end{array}$} & \multirow{2}{*}{ Active learning } \\
\hline 5 & & \\
\hline 6 & $\begin{array}{c}\text { The fact that in some of the subject sessions, my colleagues were the teachers resulted in a } \\
\text { better understanding of the concepts }\end{array}$ & \multirow{4}{*}{$\begin{array}{l}\text { Autonomous learning } \\
\text { and workload }\end{array}$} \\
\hline 7 & $\begin{array}{l}\text { Following this methodology, I feel that I truly learn and I can put into practice my knowledge } \\
\text { and skills learned in the subject }\end{array}$ & \\
\hline 8 & $\begin{array}{l}\text { The workload involved in following the methodology is excessive, so it would have been better } \\
\text { and more profitable if I had followed a learning methodology based on traditional approaches }\end{array}$ & \\
\hline 9 & $\begin{array}{l}\text { When preparing for the exams, I feel more motivated and confident than with other subjects } \\
\text { where the learning methodology is based on traditional approaches }\end{array}$ & \\
\hline 10 & I would recommend following the methodology for future students & Satisfaction \\
\hline
\end{tabular}

\subsubsection{Students' Opinion}

Once the subject classes ended, the exams were conducted and final grades were set, students were invited to submit their own opinion about the subject development and the learning methodology. This was a completely optional activity open to all students in the subject. Each student could send an email to any of the teachers or tutors for expressing their global satisfaction, as well as to indicate those aspects of the subject they liked most and/or they considered that could be improved or changed. It should be noted that, unlike the survey, this opinion was not anonymous (but given after completely finishing the subject), so it reflects the personal opinion of the student considering their own academic development.

\section{Results}

\subsection{Day-to-Day Observations}

Observations showed that from the first weeks, the fact of having to prepare a real lecture led to the students increasing their participation and involvement in the subject, especially when compared to what was observed before implementing the methodology. Session attendance considerably increased, with nearly all students attending every session. This change in the behaviour of the students was even more significant after the first month, as at that time students were already working for preparing "their own lecture". From that moment, students tried to get on time to class and they developed a good class environment.

By the second part of the subject, when the students became the lectures' teachers, they showed much more security and a natural tendency to collaborate and get fully involved in each session. Some positive collateral effects were also obtained, such as students overcoming their "stage fright" to speak in public and class discussions that even continued after the session.

Tutors also observed that the scenario of having to prepare and deliver a lecture created in first moment bewilderment, fear and disbelief in some students, as it was completely new for them. In other words, those students felt overwhelmed. Fortunately, this feeling was normally overcome after the first month of team-working in their lecture, especially thanks to the support given by the different members of their workgroup.

Moreover, teachers' meetings helped in sharing those experiences among the different tutors, so they could better guide the work of their groups, harmonize teaching methodologies between groups (so lectures were somehow not completely different one to another) 
and try groups coordinate between them to build a subject where the different topics taught were not disconnected. In addition, those meeting were also useful for detecting if things were not going well in any group. Particularly, if during a teachers' meeting, the performance of a group in one of the skills covered by the rubric (Table 1) was considered to be poor, the tutor immediately arranged a meeting with that group to dealt with the problem and solve it as soon as possible.

The work of both students and teachers made it possible that all groups participating in this experience (over the 7 years) achieved their objective of preparing and delivering a real lecture. Figure 3 illustrates a series of the class' examples of students giving lectures and developing really interesting activities. For instance, Figure 3a,b show the students of the group responsible for teaching a class related to tunnel design conducting a "Kahoot" to check the attention and knowledge of their classmates after their lecture and awarding the winner with a chocolate tablet. Figure $3 c$ shows a completely different approach: the topic "dynamic soil compaction" is taught through a real simulation prepared by the students of the group so that their classmates could understand it by experimenting and playing with the basics of this technique, as well as the effects that it brings when it is applied on a real ground. Finally, Figure 3d,e demonstrate how students themselves are the teachers of the lectures, and use videos, the blackboard and other digital resources to conduct it.

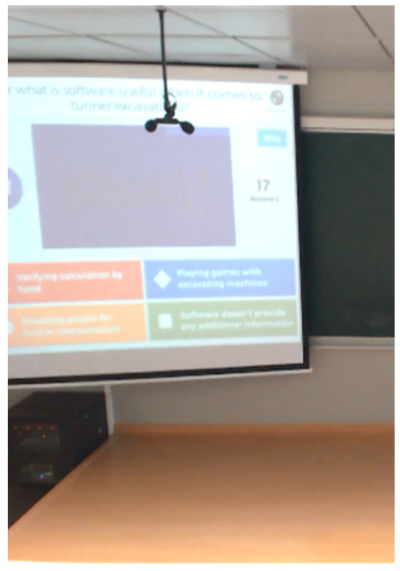

(a)

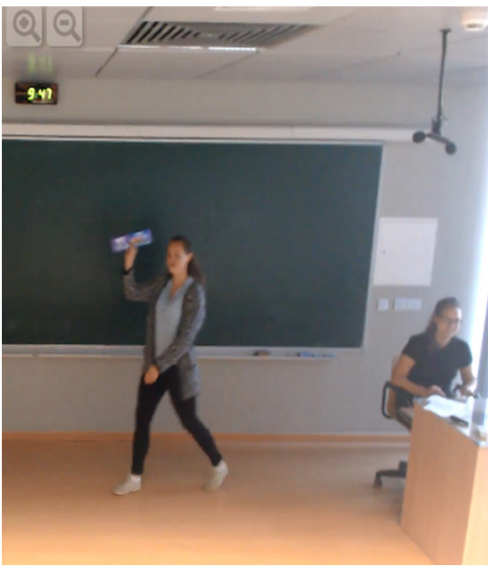

(b)

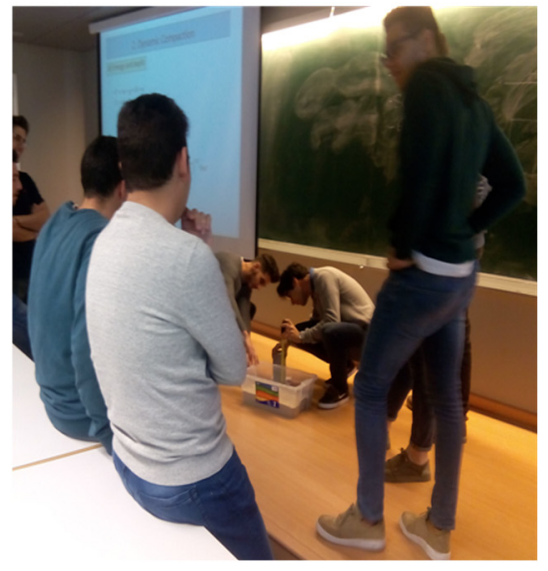

(c)

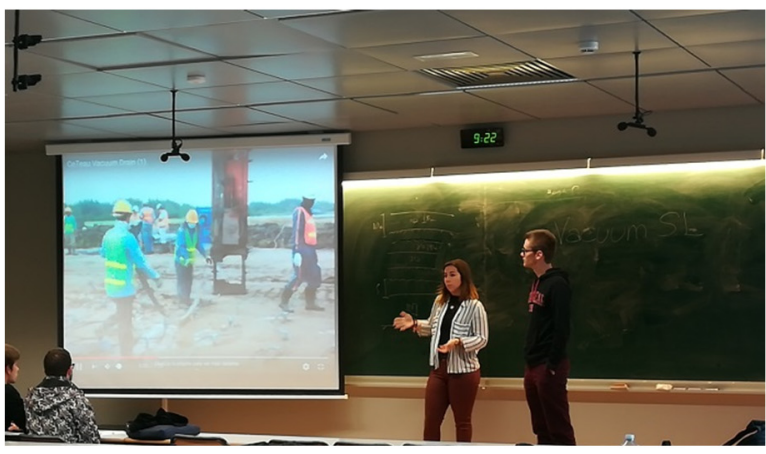

(d)

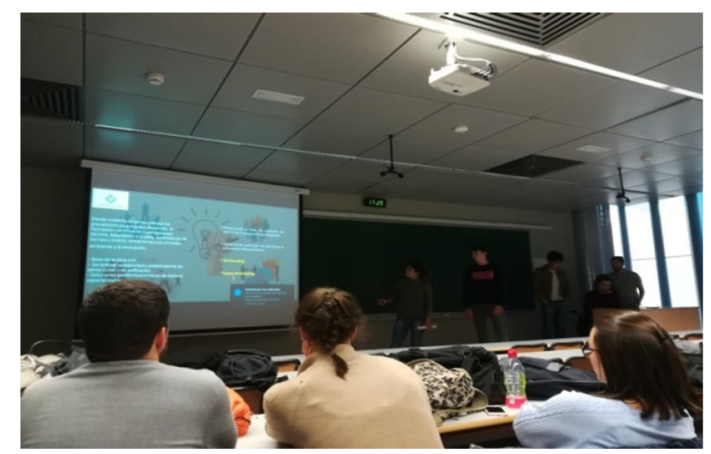

(e)

Figure 3. Examples of students giving lectures: (a) Example of a 'Kahoot' prepared by the students; (b) Award received by the student with the highest score in the 'Kahoot'; (c) Simulation prepared by the students and put into practice in the class; (d,e) Students giving their lectures using videos, slides and the blackboard. 


\subsection{Surveys}

Table 3 summarizes the results of the survey conducted at each year when the methodology was applied indicating the percentage of students who chose a given score for a question. As stated above, each question score ranges from 1 to 5 , with the higher the score, the higher the agreement with the question.

Table 3. Survey questions.

\begin{tabular}{|c|c|c|c|c|c|c|c|c|c|c|c|}
\hline \multirow{2}{*}{$\begin{array}{c}\text { Academic } \\
\text { Year }\end{array}$} & \multirow{2}{*}{ Score ${ }^{1}$} & \multicolumn{10}{|c|}{ Question } \\
\hline & & 1 & 2 & 3 & 4 & 5 & 6 & 7 & 8 & 9 & 10 \\
\hline \multirow{5}{*}{$2013 / 2014$} & 1 & $5.4 \%$ & $6.5 \%$ & $6.5 \%$ & $2.2 \%$ & $16.1 \%$ & $7.5 \%$ & $7.5 \%$ & $22.6 \%$ & $2.2 \%$ & $0.0 \%$ \\
\hline & 2 & $20.4 \%$ & $17.2 \%$ & $23.7 \%$ & $22.6 \%$ & $24.7 \%$ & $22.6 \%$ & $30.1 \%$ & $15.1 \%$ & $29.0 \%$ & $15.1 \%$ \\
\hline & 3 & $26.9 \%$ & $18.3 \%$ & $22.6 \%$ & $23.7 \%$ & $11.8 \%$ & $18.3 \%$ & $14.0 \%$ & $17.2 \%$ & $21.5 \%$ & $32.3 \%$ \\
\hline & 4 & $18.3 \%$ & $26.9 \%$ & $11.8 \%$ & $18.3 \%$ & $14.0 \%$ & $16.1 \%$ & $11.8 \%$ & $9.7 \%$ & $16.1 \%$ & $25.8 \%$ \\
\hline & 5 & $29.0 \%$ & $31.2 \%$ & $35.5 \%$ & $33.3 \%$ & $33.3 \%$ & $35.5 \%$ & $36.6 \%$ & $35.5 \%$ & $31.2 \%$ & $26.9 \%$ \\
\hline \multirow{5}{*}{$2014 / 2015$} & 1 & $3.4 \%$ & $2.7 \%$ & $3.4 \%$ & $2.7 \%$ & $7.5 \%$ & $10.2 \%$ & $1.4 \%$ & $20.4 \%$ & $2.0 \%$ & $1.4 \%$ \\
\hline & 2 & $6.1 \%$ & $8.8 \%$ & $6.1 \%$ & $10.2 \%$ & $15.0 \%$ & $10.9 \%$ & $10.9 \%$ & $21.1 \%$ & $10.9 \%$ & $5.4 \%$ \\
\hline & 3 & $15.6 \%$ & $12.2 \%$ & $23.8 \%$ & $17.0 \%$ & $14.3 \%$ & $15.0 \%$ & $17.7 \%$ & $17.0 \%$ & $21.8 \%$ & $12.2 \%$ \\
\hline & 4 & $37.4 \%$ & $38.8 \%$ & $31.3 \%$ & $38.1 \%$ & $22.4 \%$ & $21.1 \%$ & $37.4 \%$ & $16.3 \%$ & $35.4 \%$ & $52.4 \%$ \\
\hline & 5 & $37.4 \%$ & $37.4 \%$ & $35.4 \%$ & $32.0 \%$ & $40.8 \%$ & $42.9 \%$ & $32.7 \%$ & $25.2 \%$ & $29.9 \%$ & $28.6 \%$ \\
\hline \multirow{5}{*}{$2015 / 2016$} & 1 & $0.9 \%$ & $0.0 \%$ & $0.9 \%$ & $0.9 \%$ & $4.5 \%$ & $6.4 \%$ & $4.5 \%$ & $30.9 \%$ & $0.9 \%$ & $0.0 \%$ \\
\hline & 2 & $9.1 \%$ & $10.0 \%$ & $13.6 \%$ & $14.5 \%$ & $15.5 \%$ & $19.1 \%$ & $19.1 \%$ & $22.7 \%$ & $7.3 \%$ & $2.7 \%$ \\
\hline & 3 & $17.3 \%$ & $22.7 \%$ & $19.1 \%$ & $21.8 \%$ & $20.0 \%$ & $14.5 \%$ & $16.4 \%$ & $13.6 \%$ & $20.0 \%$ & $17.3 \%$ \\
\hline & 4 & $31.8 \%$ & $20.0 \%$ & $23.6 \%$ & $17.3 \%$ & $18.2 \%$ & $15.5 \%$ & $8.2 \%$ & $9.1 \%$ & $26.4 \%$ & $40.0 \%$ \\
\hline & 5 & $40.9 \%$ & $47.3 \%$ & $42.7 \%$ & $45.5 \%$ & $41.8 \%$ & $44.5 \%$ & $51.8 \%$ & $23.6 \%$ & $45.5 \%$ & $40.0 \%$ \\
\hline \multirow{5}{*}{$2016 / 2017$} & 1 & $0.0 \%$ & $1.4 \%$ & $0.0 \%$ & $0.0 \%$ & $6.8 \%$ & $9.6 \%$ & $4.1 \%$ & $35.6 \%$ & $0.0 \%$ & $0.0 \%$ \\
\hline & 2 & $15.1 \%$ & $12.3 \%$ & $15.1 \%$ & $19.2 \%$ & $16.4 \%$ & $19.2 \%$ & $26.0 \%$ & $30.1 \%$ & $11.0 \%$ & $2.7 \%$ \\
\hline & 3 & $17.8 \%$ & $13.7 \%$ & $20.5 \%$ & $20.5 \%$ & $21.9 \%$ & $12.3 \%$ & $13.7 \%$ & $5.5 \%$ & $15.1 \%$ & $27.4 \%$ \\
\hline & 4 & $28.8 \%$ & $31.5 \%$ & $24.7 \%$ & $19.2 \%$ & $13.7 \%$ & $13.7 \%$ & $8.2 \%$ & $6.8 \%$ & $26.0 \%$ & $32.9 \%$ \\
\hline & 5 & $38.4 \%$ & $41.1 \%$ & $39.7 \%$ & $41.1 \%$ & $41.1 \%$ & $45.2 \%$ & $47.9 \%$ & $21.9 \%$ & $47.9 \%$ & $37.0 \%$ \\
\hline \multirow{5}{*}{$2017 / 2018$} & 1 & $2.7 \%$ & $4.1 \%$ & $1.4 \%$ & $2.7 \%$ & $12.2 \%$ & $4.1 \%$ & $10.8 \%$ & $45.9 \%$ & $0.0 \%$ & $0.0 \%$ \\
\hline & 2 & $8.1 \%$ & $8.1 \%$ & $14.9 \%$ & $18.9 \%$ & $12.2 \%$ & $14.9 \%$ & $16.2 \%$ & $17.6 \%$ & $9.5 \%$ & $1.8 \%$ \\
\hline & 3 & $24.3 \%$ & $20.3 \%$ & $17.6 \%$ & $16.2 \%$ & $8.1 \%$ & $21.6 \%$ & $8.1 \%$ & $13.5 \%$ & $24.3 \%$ & $20.0 \%$ \\
\hline & 4 & $20.3 \%$ & $28.4 \%$ & $13.5 \%$ & $18.9 \%$ & $17.6 \%$ & $13.5 \%$ & $20.3 \%$ & $8.1 \%$ & $28.4 \%$ & $16.4 \%$ \\
\hline & 5 & $44.6 \%$ & $39.2 \%$ & $52.7 \%$ & $43.2 \%$ & $50.0 \%$ & $45.9 \%$ & $44.6 \%$ & $14.9 \%$ & $37.8 \%$ & $29.1 \%$ \\
\hline \multirow{5}{*}{$2018 / 2019$} & 1 & $0.0 \%$ & $0.0 \%$ & $0.0 \%$ & $0.0 \%$ & $1.5 \%$ & $1.5 \%$ & $0.0 \%$ & $53.0 \%$ & $0.0 \%$ & $0.0 \%$ \\
\hline & 2 & $3.0 \%$ & $4.5 \%$ & $4.5 \%$ & $1.5 \%$ & $10.6 \%$ & $12.1 \%$ & $10.6 \%$ & $22.7 \%$ & $3.0 \%$ & $0.0 \%$ \\
\hline & 3 & $10.6 \%$ & $9.1 \%$ & $10.6 \%$ & $9.1 \%$ & $16.7 \%$ & $13.6 \%$ & $16.7 \%$ & $7.6 \%$ & $9.1 \%$ & $4.5 \%$ \\
\hline & 4 & $31.8 \%$ & $37.9 \%$ & $24.2 \%$ & $37.9 \%$ & $25.8 \%$ & $15.2 \%$ & $25.8 \%$ & $9.1 \%$ & $34.8 \%$ & $34.8 \%$ \\
\hline & 5 & $54.5 \%$ & $48.5 \%$ & $60.6 \%$ & $51.5 \%$ & $45.5 \%$ & $57.6 \%$ & $47.0 \%$ & $7.6 \%$ & $53.0 \%$ & $60.6 \%$ \\
\hline \multirow{5}{*}{$2019 / 2020$} & 1 & $0.0 \%$ & $0.0 \%$ & $0.0 \%$ & $0.0 \%$ & $0.0 \%$ & $0.0 \%$ & $0.0 \%$ & $59.5 \%$ & $0.0 \%$ & $0.0 \%$ \\
\hline & 2 & $0.0 \%$ & $0.0 \%$ & $2.4 \%$ & $4.8 \%$ & $11.9 \%$ & $4.8 \%$ & $4.8 \%$ & $23.8 \%$ & $4.8 \%$ & $0.0 \%$ \\
\hline & 3 & $7.1 \%$ & $14.3 \%$ & $11.9 \%$ & $4.8 \%$ & $11.9 \%$ & $11.9 \%$ & $9.5 \%$ & $7.1 \%$ & $7.1 \%$ & $0.0 \%$ \\
\hline & 4 & $31.0 \%$ & $28.6 \%$ & $19.0 \%$ & $23.8 \%$ & $19.0 \%$ & $21.4 \%$ & $21.4 \%$ & $9.5 \%$ & $21.4 \%$ & $33.3 \%$ \\
\hline & 5 & $61.9 \%$ & $57.1 \%$ & $66.7 \%$ & $66.7 \%$ & $57.1 \%$ & $61.9 \%$ & $64.3 \%$ & $0.0 \%$ & $66.7 \%$ & $66.7 \%$ \\
\hline
\end{tabular}

${ }^{1}$ Scores range from 1 to 5 , the higher the score the higher the agreement with the question.

Results show that in the first year (academic year 2013/2014), the scores were not high, probably because many students did not understand the aim of the methodology and disagreed with the fact of having to work "more" than their colleagues of the previous year. The experience of the teachers in the implementation of the methodology was low, and likely this also led to creating a bit of confusion in the students for what was expected from them. The next two years (academic years 2014/2015 and 2015/2016) reflect a slight improvement in the survey results. Probably, students became more familiar with the methodology as their colleagues did comment on it, causing them to be more open to an active learning approach. However, in this period, results were also affected by the 
fact of having a great number of students (around 150). From that point, survey results improved significantly, as the methodology was then completely known and accepted by the students, the number of students decreased (less than 100) and the experience of the teachers increased continuously.

Figure 4 depicts the previous results grouped by topics, i.e., questions $1+2+3$ (motivation and engagement), $4+5+6$ (active learning), $7+8+9$ (autonomous learning and workload) and 10 (satisfaction). Questions related to motivation and engagement of students and active learning show a similar performance, which indicates the close relationship that exists between both topics. A significant improvement in the scores is seen after the first year of implementation, where about $50 \%$ of students gave a high score (4 or 5). From the second year, this percentage increases up to $70 \%$.

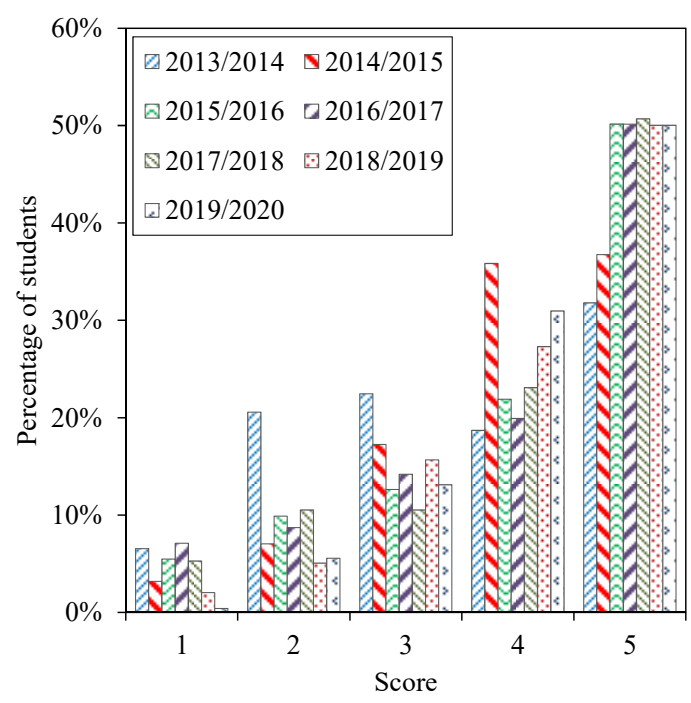

(a)

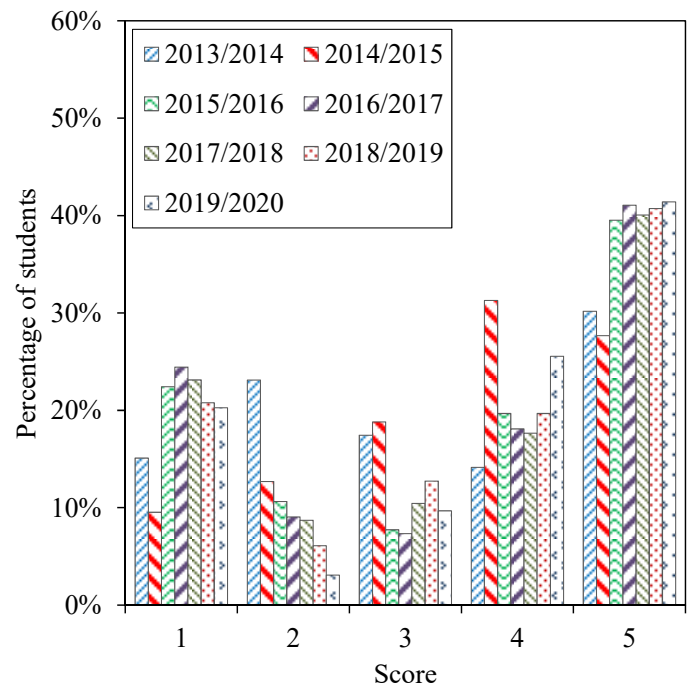

(c)

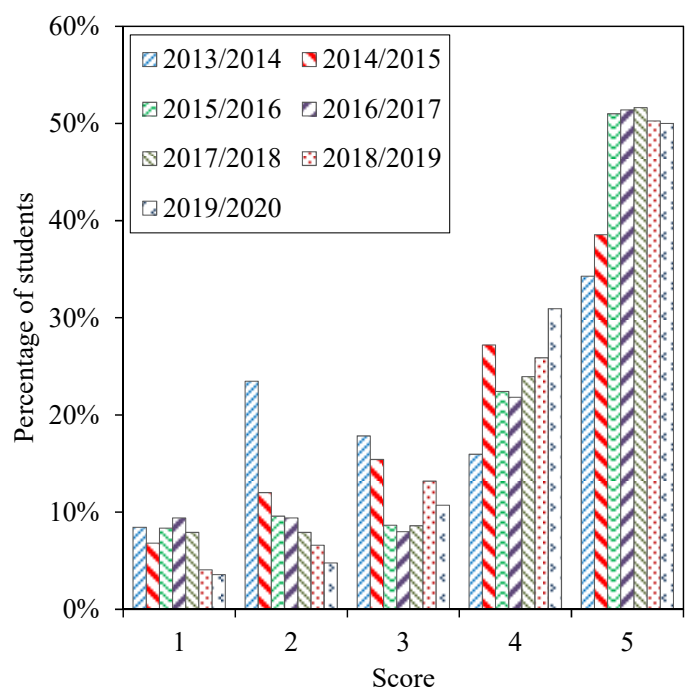

(b)

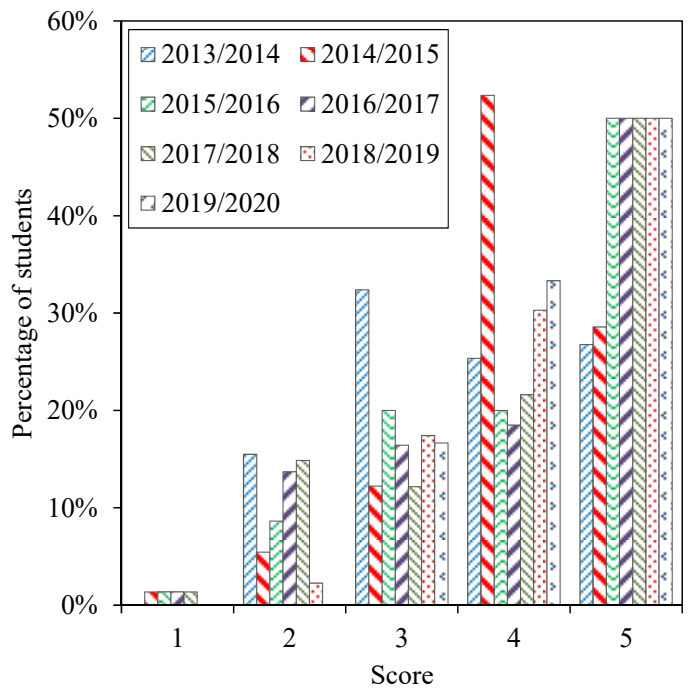

(d)

Figure 4. Survey results grouped by topics: (a) Motivation and engagement; (b) Active learning strategies; (c) Autonomous learning and workload; (d) Satisfaction.

Autonomous learning and workload results show the mentioned issue related to the "necessity of working more" in the first years, tending the scores to increase after the second year. Note that, for grouping questions, scores given to question 8 (which answer is "opposed" to the rest) were inverted. Regarding question 10, results show that, except 
for the first year, the majority of students would recommend the methodology to future colleagues, with high scores even achieving more than $80 \%$ in the last two years.

\subsection{Students' Opinion}

Approximately $60 \%$ of students each year sent an opinion to the teachers after finishing the subject. In some cases, such opinions were short and only showed the student's global satisfaction. However, some students gave interesting feedback. In general terms, nearly all students valued the possibility of learning together with their classmates, both inside and outside the classroom. As expected, the creation of a good social environment fostered the learning process and made the learning experience more enjoyable.

The assessment system of the subject was also positively valued, with some students indicating that motivation to attend to class and work on it helped them to arrive better prepared for the exams. In terms of global satisfaction (similar to the results obtained in the surveys) most students liked the teaching methodology and considered it to be more appropriate than classical ones where they only have to go to class to listen to the professor and later study at home. They also felt that they have truly learned something in the subject, and they were more confident about the application of their engineering knowledge.

Conversely, some students indicated they prefer the classical approach since they were more comfortable with it; similarly, other students alleged that the workload was sometimes excessive. In any case, many students liked the experience of both preparing and delivering a lecture, as it showed them the necessity of delving into a topic and clearly understanding it before being able to explain it to others. They also expressed that the experience made them value more the role of the teacher and the necessity of any kind of assessment to control the learning of students.

\subsection{Academic Performance}

An assessment of the academic results showed the impact of the learning methodology on the performance of the students when compared with the academic results of the reference year (2012/2013). By increasing the motivation and fostering active learning, the performance of the students was expected to increase.

Academic results gathered during the seven years of the methodology application are shown in Figure 5, where the results corresponding to the reference year are also included. It should be mentioned that the data consider all students, i.e., those who follow the proposed methodology, those who preferred not to enrol, and those who completely abandoned the subject due to different circumstances.

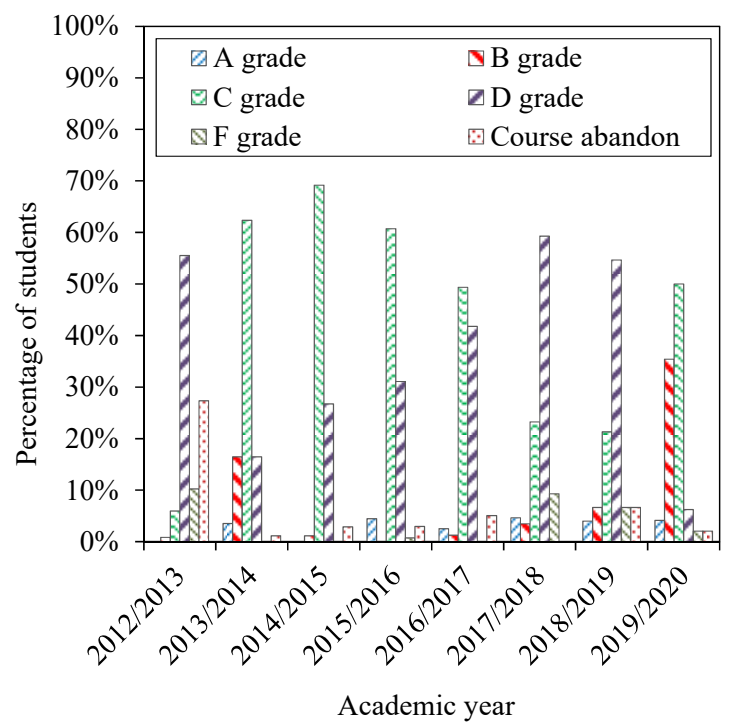

Figure 5. Students' academic performance. 
The reference year academic results show that more than $50 \%$ of students reached D grades, whilst the number of $C$ grades was low. Only $1 \%$ obtained a B grade and none of them achieved an A. About $6 \%$ of students failed (F grade), and course abandonment was about $25 \%$, which may be considered high. Thus, in total, more than a third of students did not pass the subject. Implementation of the new methodology introduced changes in this scenario. The most important aspect was the drastic decrease in the number of students who abandoned the course or did not pass. Thus, course abandonment was reduced to a maximum of $7 \%$, and $\mathrm{F}$ grades nearly disappeared.

Moreover, $\mathrm{C}$ grades significantly increased, and higher grades (A and B grades) also slightly rose. In particular, the amount of A grades was set at around 5\% during the implementation of the new methodology. It should be noted that the exam done during the reference year was divided into two parts, comprising the same syllabus distribution as the one showed in Figure 2. Therefore, topics belonging to the first part were, in both cases, evaluated with an exam of the same structure and difficulty level. For the second part, the exam done during the reference year proposed real engineering cases, meaning that the student had to apply their knowledge acquired at the class sessions and give an engineering solution, expressing it as if they were the practitioner. Thus, this is comparable to assess soft skills such as practical thinking, critical thinking and effective communication, which are better assessed in the new learning methodology through a rubric-based co-evaluation (see Table 1). All in all, both academic results may be considered comparable.

From the academic year 2017/2018, an exam replaced the tutor co-evaluation (student evaluation remained) for the second part of the subject. During academic years 2017/2018 and 2018/2019, the amount of A and B grades were similar to previous years, but D grades were higher than $C$, although that amount did not reach the values of the reference academic year. Apparently, not having any reference to exams in the previous years may have given rise to some confusion in some students about how to face the subject, thus reducing their grades. However, in general, exam results of the second part did not deviate much from the grades that would have resulted from the evaluation of tutors using the rubric. Finally, in the academic year 2019/2020, the tendency of having more C grades than D grades returns. Besides, during this last year, the number of B grades achieved significantly increased.

\section{Discussion}

After seven years, the learning methodology, which was based on the combination of PBL and cooperative learning through an activity involving the preparation of a real lecture by students, showed its capability to: (i) increase students' engagement in the subject; (ii) move the students from a passive role to an active one; (iii) facilitate knowledge and skills acquisition whilst facilitating the long-term retention of that knowledge; (iv) develop the soft skills of team-working, practical thinking, effective communication and critical thinking; and ( $v$ ) reduce students absenteeism and enhance the academic performance.

The different results provided by observations, surveys and the direct opinions of the students indicate that the implementation of the learning methodology helped students to follow the subject and show interest in it. Once students started to work outside the classroom via the activity of preparing and delivering their real lecture, they tended to attend class regularly and try to keep the subject up-to-date, participation rose and students started to see the teacher more as a guide than as an examiner. The existing traditional gap between students and teachers was reduced, and the students felt more comfortable and secure in class and more confident when putting into practice their knowledge and skills. All of those aspects create a good social environment which promotes the activeness of the students in class.

As a result, many students appear to develop deep-level learning [11], which is supported by affirmations of students such as that they feel they are truly learning, and/or that they consider arriving better prepared and confident in the exams. Moreover, the additional workload introduced by the methodology does not represent a big concern for 
many students. Results also show the close relationship existing between engagement and knowledge and skills acquisitions. As reported by other authors $[4,38,54]$, increasing one of them results in increasing the others. For instance, engagement promotes interest in the subject and a tendency to acquire knowledge and skills. At the same time, knowledge often results in the need to acquire more knowledge, which increases motivation and engagement.

Further, students acquired and improved the soft skills, such as team-working, practical thinking, effective communication and critical thinking, thanks to the implementation of the learning methodology proposed. The development of such skills was controlled and assessed regularly by the teachers using a rubric (see Table 1). Occasional problems were detected and quickly corrected thanks to continuous monitoring. Results showed that all students enrolled in the methodology achieved at least a "Fair" level of those skills. Furthermore, the application of the methodology especially fosters team-working as a result of using cooperative learning, a skill very positively valued in the labour market. Similarly, the methodology develops the students' technical criticism capacity, a desired skill that is sometimes forgotten when planning a subject (normally more focused on providing technical knowledge). Both the preparation of the lecture and the assessment of those given by the other groups contribute to this. Thus, the co-evaluation designed promotes the ability of the students to technically select and present the information that they consider interesting for their target audience (in this case, the rest of their classmates) and discuss the work carried out by others.

A better grounding in knowledge and skills is also reflected in the academic performance of the students, which clearly improves when compared with the academic year when a classical methodology was used. A general improvement is observed, especially an increment in $\mathrm{C}$ grades accompanied by a lowering in $\mathrm{D}$ grades, being the number of F grades (failing) very low or even null in some years. Thus, the methodology shows its ability for enhancing the performance of the average students. The number of higher grades (A and B grade) is less affected in general, i.e., good students remain good, and the methodology does not artificially leap average students into a higher tier. In terms of absenteeism, this is nearly suppressed. Taking into account the total number of students who have been enrolled in the subject since 2013, when the new methodology was launched, from 680 students, only 20 abandoned the subject. That figure represents less than 3\% of the total students. Increased motivation and engagement, the introduction of an active learning approach and a more appealing evaluation system (based on a co-evaluation) may be the reasons for some students not to abandon and get interested in the subject.

The proposed learning methodology also reaches a high level of satisfaction. This appears to be the result of four contributions: the good class environment created at class and the activities proposed, both of which motivate the students to attend and follow the sessions; the high level of engagement attained, which has demonstrated to greatly influence satisfaction $[4,55,56]$; the optimal acquisition of knowledge and skills (especially soft skills), an issue which has been proven by several researchers [4,57,58]; and a continuous and fair evaluation system, which focuses on the activities carried out inside and outside the class, along with the development of the subject.

Finally, it should be mentioned that for decades, education at the Civil Engineering Schools in Spain was exclusively based on a teacher-centred approach, fundamentally using the Master's class. Particularly, at the Civil Engineering School of Valencia, any activity different to an exam, including any individual guided work or the presentation of a given topic in class, was something non-existent neither in the syllabus nor in the day-to-day students' experience. Thus, even though activities like the one proposed in this paper may seem common today, in terms of teaching at the Civil Engineering School of Valencia, almost meant a revolutionary change. Older teachers were reluctant to implement this type of teaching methodology (student-centred approaches), due to either custom or tradition. Since those teachers tend to be the subjects' coordinators, transition to student-centred approaches is slow and difficult. 
Fortunately, the good results showed by learning strategies such as PBL, cooperative learning and flip teaching are helping to implement these teaching methodologies in Civil Engineering education. Thus, the methodology proposed in this paper was only applied to the second part of the subject due to some of the issues mentioned, but it is expected to be applied in the future to the whole as well as other subjects at the Civil Engineering School of Valencia. Further work will be then conducted to compare the students' performance among different subjects and assess the skill and knowledge acquisition using this methodology when compared with the traditional teacher-centred approach.

Author Contributions: Conceptualization, F.J.T. and J.G.-R.; methodology, F.J.T. and J.G.-R.; software, M.Á.E.; validation, M.Á.E. and G.C.; investigation, F.J.T. and J.G.-R.; writing-original draft preparation, J.G.-R.; writing-review and editing, F.J.T. and M.Á.E.; visualization, F.J.T. and G.C.; supervision, G.C.; project administration, G.C. All authors have read and agreed to the published version of the manuscript.

Funding: This research received no external funding. The authors fully acknowledge the financial support provided by the Department of Geological and Geotechnical Engineering of the UPV.

Institutional Review Board Statement: Not applicable.

Informed Consent Statement: Not applicable.

Data Availability Statement: The data presented in this study are available on request from the corresponding author. The data are not publicly available due to privacy reasons.

Conflicts of Interest: The authors declare no conflict of interest.

\section{References}

1. Ngereja, B.; Hussein, B.; Andersen, B. Does Project-Based Learning (PBL) Promote Student Learning? A Performance Evaluation. Educ. Sci. 2020, 10, 330. [CrossRef]

2. Roach, T. Student perceptions toward flipped learning: New methods to increase interaction and active learning in economics. Int. Rev. Econ. Educ. 2014, 17, 74-84. [CrossRef]

3. Hernández-López, L.; García-Almeida, D.J.; Ballesteros-Rodríguez, J.L.; De Saá-Pérez, P. Students' perceptions of the lecturer's role in management education: Knowledge acquisition and competence development. Int. J. Educ. Manag. 2016, 14, 411-421. [CrossRef]

4. Murillo-Zamorano, L.R.; López Sánchez, J.A.; Godoy-Caballero, A.N. How the flipped classroom affects knowledge, skills, and engagement in higher education: Effects on students' satisfaction. Comput. Educ. 2019, 141, 103608. [CrossRef]

5. Clanchy, J.; Ballard, B. Generic Skills in the Context of Higher Education. High. Educ. Res. Dev. 1995, 14, 155-166. [CrossRef]

6. Chang, C.-C.; Kuo, C.-G.; Chang, Y.-H. An assessment tool predicts learning effectiveness for project-based learning in enhancing education of sustainability. Sustainability 2018, 10, 3595. [CrossRef]

7. Bedggood, R.E.; Donovan, J.D. University performance evaluations: What are we really measuring? Stud. High. Educ. 2012, 37, 825-842. [CrossRef]

8. Bonwell, C.C. Enhancing the lecture: Revitalizing a traditional format. New Direct. Teach. Learn. 1996, 67, 31-44. [CrossRef]

9. Shakarian, D.C. Beyond lecture: Active learning strategies that work. J. Phys. Educ. Recreat. Danc. 1995, 66, 21-24. [CrossRef]

10. Vogler, J.S.; Thompson, P.; Davis, D.W.; Mayfield, B.E.; Finley, P.M.; Yasseri, D. The hard work of soft skills: Augmenting the project-based learning experience with interdisciplinary teamwork. Instr. Sci. 2018, 46, 457-488. [CrossRef]

11. Marton, F.; Säljö, R. On qualitative differences in learning: Outcome and process. Br. J. Educ. Psychol. 1976, 46, 4-11. [CrossRef]

12. Chin, D.B.; Chi, M.; Schwartz, D.L. A comparison of two methods of active learning in physics: Inventing a general solution versus compare and contrast. Instr. Sci. 2016, 44, 177-195. [CrossRef]

13. Kelly, W. Certification and Accreditation in Civil Engineering. J. Prof. Iss. Eng. Ed. Pract. 2007, 133, 181-187. [CrossRef]

14. Gavin, K. Case study of a project-based learning course in civil engineering design. Eur. J. Eng. Educ. 2011, 38, 547-558. [CrossRef]

15. Mgangira, M.B. Integrating the Development of Employability Skills into a Civil Engineering Core Subject through a ProblemBased Learning Approach. Int. J. Eng. Educ. 2003, 19, 759-761.

16. Brundiers, K.; Wiek, A. Do we teach what we preach? An international comparison of problem- and project-based learning courses in sustainability. Sustainability 2013, 5, 1725-1746. [CrossRef]

17. Krajcik, J.S.; Shin, N. Project-based learning. In the Cambridge Handbook of the Learning Sciences; Sawyer, R.K., Ed.; Cambridge University Press: Cambridge, UK, 2014; pp. 275-297.

18. Bell, S. Project-based learning for the 21st century: Skills for the future. Clear. House J. Educ. Strateg. Issues Ideas $2010,83,39-43$. [CrossRef]

19. Chinnowsky, P.; Brown, H.; Szajnman, A.; Realph, A. Developing knowledge landscapes through project-based learning. J. Prof. Iss. Eng. Ed. Pract. 2006, 132, 118-125. [CrossRef] 
20. Gijselaers, W.H. Connecting problem-based learning with educational theory. In Bringing Problem-Based Learning to Higher Education: Theory and Practice; Wilkerson, L., Gijselaers, W.H., Eds.; Jossey-Bass: San Francisco, CA, USA, 1996 ; pp. $13-21$.

21. Johnson, P.A. Project-based, cooperative learning in the engineering classroom. J. Prof. Iss. Eng. Ed. Pract. 1999, $125,8-11$.

22. Padmanadhan, G.; Katti, D. Using community-based projects in civil engineering capstone courses. J. Prof. Iss. Eng. Ed. Pract. 2002, 125, 12-18.

23. Parsons, C.; Caylor, E.; Simmons, H. Cooperative Education Work Assignments The role of Organizational and Individual Factors in Enhancing ABET Competencies and Cp-op Workplace Well-Being. J. Eng. Educ. 2005, 94, 309-316. [CrossRef]

24. Mulcahy, D. Turning the contradictions of competence: Competence-based training and the beyond. J. Vocat. Educ. Train. 2000, 52, 259-280. [CrossRef]

25. Kelson, A.C.; Distlehorst, L.H. Group in problem-based learning (PBL): Essential elements in theory and practice. In Problem-Based Learning: A Research Perspective on Learning Interactions; Evensen, D.H., Hmelo, C.E., Eds.; Lawrence Erlbaum: Mahwah NJ, USA, 2000; pp. 167-184.

26. Boyle, P.; Trevitt, C. Enhancing the quality of student learning through the use of subject learning plans. High. Educ. Res. Dev. 1997, 16, 293-308. [CrossRef]

27. Felder, R.; Woods, D.; Stice, J.; Rugarcia, A. The Future of Engineering Education: Teaching Methods that Work. Chem. Eng. Educ. 2000, 34, 26-39.

28. Cinar, Y.; Bilgin, A. Peer Assessment for undergraduate Teamwork Projects in Petroleum Engineering. Int. J. Eng. Educ. 2011, 27, 310-322.

29. Johnson, D.W.; Johnson, R.T.; Smith, K. The state of cooperative learning in postsecondary and professional settings. Educ. Psychol. Rev. 2007, 19, 15-29. [CrossRef]

30. Shimazoe, J.; Aldrich, H. Group work can be gratifying: Understanding \& overcoming resistance to cooperative learning. Coll. Teach. 2010, 58, 52-57.

31. Munir, M.T.; Baroutian, S.; Young, B.R.; Carter, S. Flipped classroom with cooperative learning as a cornerstone. Educ. Chem. Eng. 2018, 23, 25-33. [CrossRef]

32. Springer, L.; Stanne, M.E.; Donovan, S.S. Effects of small-group learning on undergraduates in science, mathematics, engineering, and technology: A meta-analysis. Rev. Educ. Res. 1999, 69, 21-51. [CrossRef]

33. Dym, C.L.; Agogino, A.M.; Eris, O.; Frey, D.D.; Leifer, L.J. Engineering design thinking, teaching, and learning. J. Eng. Educ. 2005, 94, 103-120. [CrossRef]

34. Hassanien, A. A qualitative student evaluation of group learning in higher education. High. Educ. Eur. 2007, 32, 135-150. [CrossRef]

35. Johnson, D.W.; Johnson, R.T. Cooperative Learning; Wiley Online Library: Hoboken, NJ, USA, 2008.

36. Reyes, E.; Gálvez, J.C. Introduction of Innovations into the Traditional Teaching of Construction and Building Materials. J. Prof. Iss. Eng. Ed. Pract. 2011, 137, 28-37. [CrossRef]

37. Herrmann, K.J. The impact of cooperative learning on student engagement: Results from an intervention. Act. Learn. High. Educ. 2013, 14, 175-187. [CrossRef]

38. Fredricks, J.A.; Wang, M.T.; Linn, J.S.; Hofkens, T.L.; Sung, H.; Parr, A. Using qualitative methods to develop a survey measure of math and science engagement. Learn. Instr. 2016, 43, 5-15. [CrossRef]

39. Shernoff, D.J.; Kelly, S.; Tonks, S.M.; Anderson, B.; Cavanagh, R.F.; Sinha, S. Student engagement as a function of environmental complexity in high school classrooms. Learn. Instr. 2016, 43, 52-60. [CrossRef]

40. Monroy, R.; Torrijo, F.J.; Hernández-Pina, F. Lecturers' perceptions of students' learning needs in geo-engineering in Spain. In Shaking the Foundations of Geo-Engineering Education; McCabe, P., Phillips, Eds.; Taylor \& Francis Group: London, UK, 2012.

41. Torrijo, F.J.; Cortés, R.; Valiente, R. Indagación y mejora docente en el campo de la Geología Aplicada [Teaching improvment and research in applied geology]. In Jornadas de Innovación Educativa 2012; Universitat Politècnica de València: Valencia, Spain, 2012. (In Spanish)

42. Torrijo, F.J.; Garzón-Roca, J.; Cobos, G.; Alija, S. Implementación de la metodología de Clase Inversa en el campo de la Ingenieria del Terreno. [Implementing the flipped classroom methodology in geotechnical engineering]. In International Conference on Innovation, Documentation and Education, INNODOCT 2017; Universitat Politècnica de València: Valencia, Spain, 2017. (In Spanish)

43. Garzón-Roca, J.; Torrijo, F.J.; Cobos, G.; Fernández, L. May be Geotechnical Engineering learning fun? In Proceedings of the IV International Conference on Civil Engineering Education, EUCEET, Barcelona, Spain, 5-8 September 2018.

44. Bloom, B.S.; Krathwohl, D.R. Taxonomy of Educational Objectives: The Classification of Educational Goals by a Committee of College and University Examiners. In Handbook I: Cognitive Domain; Longmans: London, UK, 1956.

45. Bergmann, J.; Sams, A. Flip Your Classroom: Reach Every Student in Every Class Every Day; International Society for Technology in Education: Washington, DC, USA, 2012.

46. Mason, G.S.; Shuman, T.R.; Cook, K.E. Comparing the effectiveness of an inverted classroom to a traditional classroom in an upper-division engineering course. IEEE Trans. Educ. 2013, 56, 430-435. [CrossRef]

47. Love, B.; Hodge, A.; Grandgenett, N.; Swift, A.W. Student learning and perceptions in a flipped linear algebra course. Int. J. Math. Educ. Sci. Technol. 2014, 45, 317-324. [CrossRef]

48. O'Flaherty, J.; Phillips, C. The use of flipped classrooms in higher education: A scoping review. Internet High. Educ. 2015, 25, 85-95. [CrossRef] 
49. Gilboy, M.B.; Heinerichs, S.; Pazzaglia, G. Enhancing student engagement using the flipped classroom. J. Nutr. Educ. Behav. 2015, 47, 109-114. [CrossRef] [PubMed]

50. Hao, Y. Exploring undergraduates' perspectives and flipped learning readiness in their flipped classrooms. Comput. Hum. Behav. 2016, 59, 82-92. [CrossRef]

51. Hotle, S.L.; Garrow, L.A. Effects of the Traditional and Flipped Classrooms on Undergraduate Student Opinions and Success. J. Prof. Iss. Eng. Ed. Pract. 2016, 142, 05015005. [CrossRef]

52. Lo, C.K.; Hew, K.F. The impact of flipped classrooms on student achievement in engineering education: A Meta-Analysis of 10 years of research. J. Eng. Educ. 2019, 108, 129-143. [CrossRef]

53. Gómez-Tejedor, J.A.; Vidaurre, A.; Tort-Ausina, I.; Molina-Mateo, J.; Serrano, M.A.; Meseguer-Dueñas, J.M.; Martínez Sala, R.M.; Quiles, S.; Riera, J. Effectiveness of flip teaching on engineering students' performance in the physics lab. Comput. Educ. 2020, 144, 103708. [CrossRef]

54. Wang, M.T.; Holcombe, R. Adolescents' perceptions of school environment, engagement, and academic achievement in middle school. Am. Educ. Res. J. 2010, 47, 633-662. [CrossRef]

55. Eom, S.B.; Wen, H.J.; Ashill, N. The determinants of students' perceived learning outcomes and satisfaction in university online education: An empirical investigation. Decis. Sci. J. Innov. Educ. 2006, 4, 215-235. [CrossRef]

56. Gray, J.A.; DiLoreto, M. The effects of student engagement, student satisfaction, and perceived learning in online learning environments. Int. J. Educ. Leadersh. Prep. 2016, 11, 1-20.

57. So, H.J.; Brush, T.A. Student perceptions of collaborative learning, social presence and satisfaction in a blended learning environment: Relationships and critical factors. Comput. Educ. 2008, 51, 318-336. [CrossRef]

58. Eom, S.B.; Ashill, N. The determinants of students' perceived learning outcomes and satisfaction in university online education: An update. Decis. Sci. J. Innov. Educ. 2016, 14, 185-215. [CrossRef] 